\title{
A PRELIMINARY REPORT ON ARCHAEOLOGICAL FINDINGS IN AURUKUN SHIRE, WESTERN CAPE YORR.
}

\section{ROGER CRIBB}

Division of Anthropology

South Australian Museum

\section{INTRODUCTION}

The following is a preliminary report on archaeological work undertaken in september and october 1985 in conjunction with an ethnographic mapping project carried out by the South Australian Museum and Aurukun Shire council. The mapping project, which has continued in some form for the past 15 years, was set up by anthropologists peter sutton and John von sturmer along with the traditional owners of clan estates. As this work, and similar work in eastern Cape York, has had as one of its primary aims the elucidation of traditional patterns of land tenure, it represents a major potential resource for archaeology (chase 1980; Sutton 1978; von sturmer 1978).

Previous archaeological work on the west coast (Bailey 1977) and in Princess Charlotte Bay on the east (Beaton 1985), together with investigations of rockshelters in the sandstone escarpments around Laura (Rosenfeld et al 1981, Wright 1971), has occurred within a rough transect across the peninsula (Figure 1). The transect encompasses a broad coastal plain on the west, great tracts of open sclerophyl country, the Great Dividing Range and a narrower coastal margin on the east. It forms a natural laboratory for the study af past human settlement at a regional level in the light of available data on contemporary and recent patterns. Occupation levels at Early Man shelter near Laura range from 13,000 BP until recent.ly (Rosenfeld et al 1.981), while occupation of rock shelters on the east coast has been dated to the mid-Holocene (Beaton 1985). Dates from the weipa shell mounds on the west coast of Cape York Peninsula (Bailey 1977) are more recent, mainly within the last 1000 years. Archaeological coverage has been irregular and the outline of the region's prehistory is still poorly understood (see Campbell 1985). This paper alms to present some preliminary archaeological findings from Aurukun in the hope of stimulating further research within a regional and interdisciplinary framework in Cape York Peninsula. 


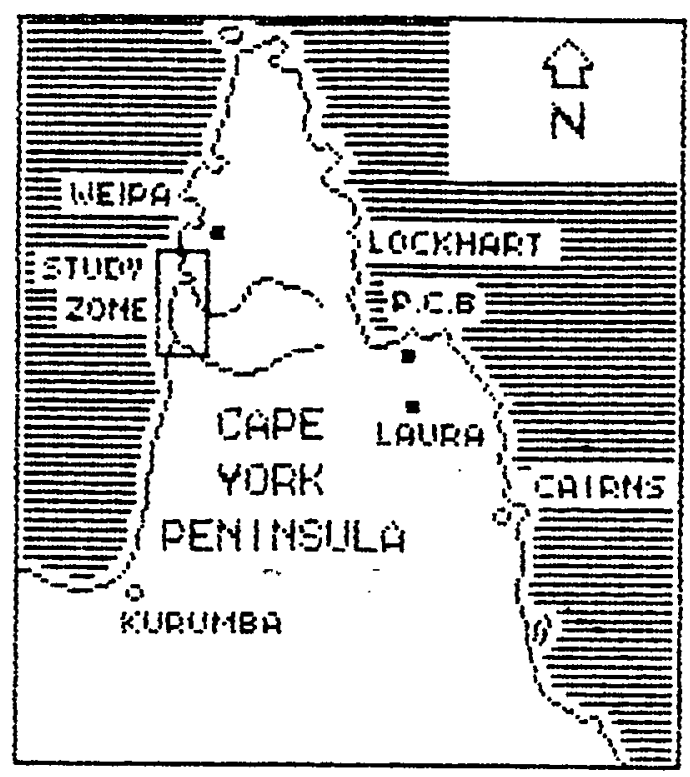

Figure 1. Map of Cape York Peninsula showing excavated sites and the Aurukun study area.

GEOLOGICAI HISTORY AND LANDFORMS OF THE AURUKUN REGION

A detailed knowledge of the present topography and the formation of geological zones is vital to any archaeological study of the Aurukun region. What follows is an initial attempt to reconstruct a geological sequence against which the archaeological evidence may be evaluated.

Today the region comprises seven main environmental zones easily discernible by the plant communities inhabiting each (Smyth 1981; Chase and Von sturmer 1980; Pedley 1971; Sutton 1978). Working eastward from the coast, there occurs a strandline complex consisting of recently formed, mobile beach ridges topped by salt resistant vegetation. These are followed by parallel systems of Holocene dunes running north-south, surmounted by alternating areas of open dune woodland and vine scrubs. The broad, black silt plains which occur further east are easily identifled by vehicle. The silt supports only grassland with occasional stands of pandanus in the higher regions. Saltpan occurring in the inter-tidal zone is devoid of vegetation but the compacted surface provides easier access by foot or by vehicle. Mangroves follow the arms of tidal streams winding their way across the saltpan from the wide silt plains. A further band of silt plain occurs inland of the mangrovesaltpan complex. Next comes a zone of silt which is above the reach of the highest tides and all but the highest floodwaters as evidenced by the presence of large termite mounds. This zone supports an open savannah vegetation. It borders on the remnants of an extensive pleistocene dune system which supports a plant community of eucalypts and vine thicket. Finaliy the dunes give way to open sclerophyl woodland dotted with swamps occupying circular depressions, gradually. ascending to the outlierg of the Great Dividing Range (Figure 2). 


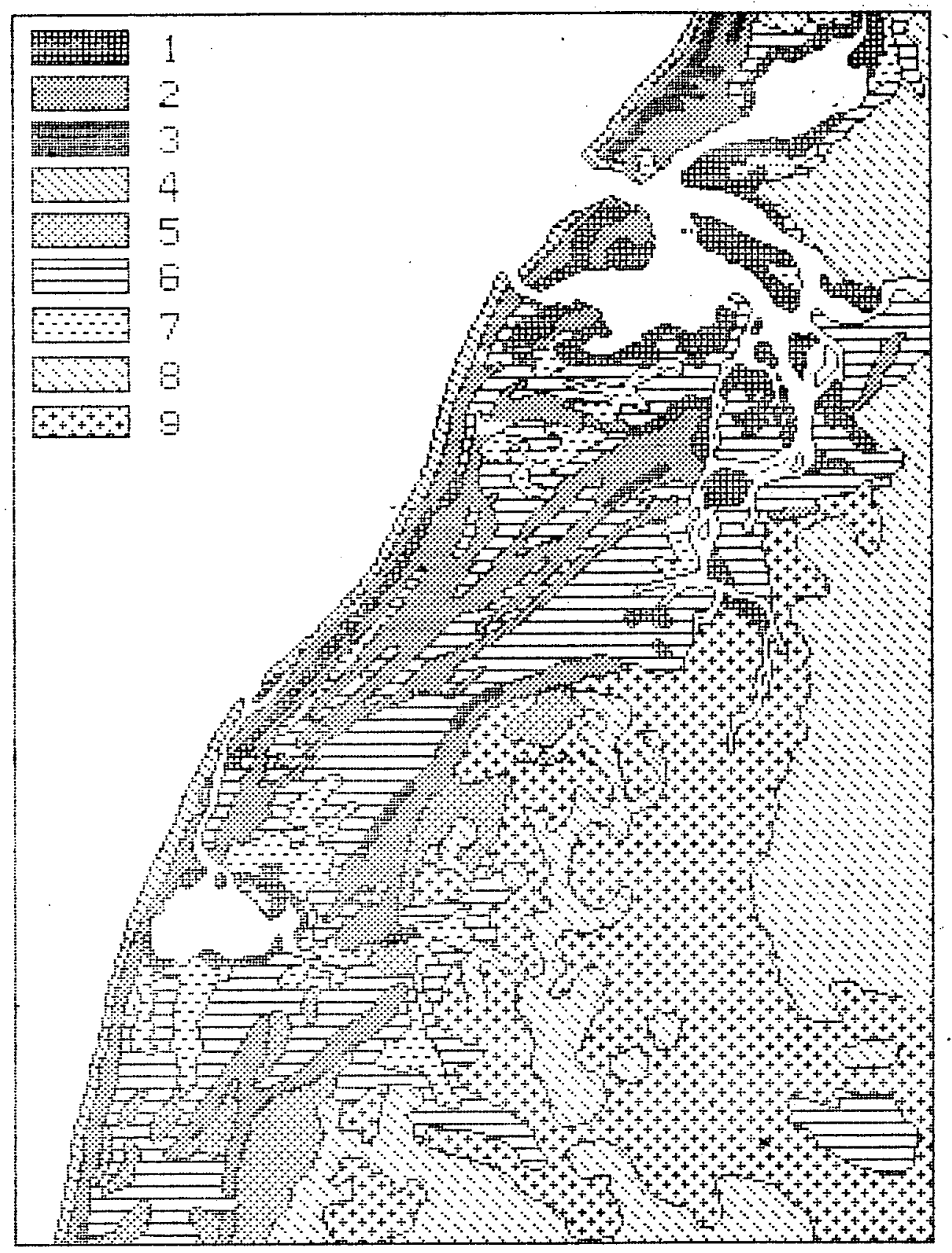

1. Mangrove

2. Open dune woodland

3. Aquifer vine forest

4. Strand complex

5. Monsoon tree savannah
6. Silt

7. Salt pan

8. Monsoon forest

9. Monsoon eucalypt woodland

Figure 2. Computer-generated map of plant communities in the study zone.

The zones are generally clearly demarcated except in the case of degraded dune systems where vine scrub may persist on a silt subsoli. variations on this ideal cross-section do occur. For instance, 1 ines of parallel coastal dunes may be separated by zones of silt, swamps saltpan and mangrove. 
The geological history of the region (Rhodes 1980; Smart 1976; 1977; Thom 1964) reads in roughly reverse order to that listed above (Figure 3). The sandy matrix which now supports sclerophyl woodland is oldest. The Pleistocene dunes were deposited on the last major interglacial maximal beachline approximately 120,000 years ago and probably formed the initial Holocene coastline about 6000 BP (Rhodes 1980 ). These dunes, rising up to $3 \mathrm{~m}$ above the current sea level, have apparent$1 y$ been mistaken for early Holocene dunes by at least one researcher (Valentin 1961). During the early Holocene, offshore sandspit formation produced the easternmost 1 ine of coastal dunes (Smart 1976; Thom 1964). Siltation of the intervening lagoon then commenced. The areas of high silt now covered by savannah may have been deposited at this time, particularly around the mouths of streams.

With a slight drop in sea level around $5000 \mathrm{BP}$, stabilization of the seaward dune system occurred and rejuvenation of streams resulted in increased siltation. This process has continued up to the present against the background of a steadily falling sea level due to postglacial isostatic warping (Chappel1 1983; Chappel1 et al 1982).

Mangroves have been a primary agent of accretion, advancing along the lagoon shoreline and up the tidal arms and saltpans of the intertidal zone. With the formation of seaward deltas stabilized by vegetation at the river and creek mouths, further lines of parallel sand dunes have evolved out of offshore sandspits forming, where longshore drift permits, extensive sandridge systems such as that south of Cape Keerweer and north of the Love River (Figure 2).

In terms of geological context alone, the probability of locating early Holocene or Pleistocene sites is not high. At best one might anticipate finding some mid-Holocene sites on the landward chains of Holocene dunes. Any Pleistocene or early Holocene sites would be confined to the Pleistocene dune line or the unexplored sclerophyl country to the east (see smyth 1981).

\section{SEASONS, RESOURCES AND SETTLEMENT}

The annual pattern of resource exploitation is heavily influenced by seasonal extremes of rainfall (Thomson 1939). Western cape York represents one of the most extreme cases of seasonal contrast in the tropical world (Pedley 1971). For approximately three months each year from late December to March, the entire area west of the Pleistocene dune system, except for the dunes and the higher parts of the savannah, becomes a vast inland sea so that it is possible to travel by boat from the Archer mouth south to the Kendall River and beyond without touching land. The Archer River itself, a tiny trickle in the dry season, becomes a raging torrent. After the 1984-85 wet season (a particularly heavy one) the carcasses of bullocks could be seen deposited in tree branches some $6 \mathrm{~m}$ high. The sea itself becomes diluted with fresh water runoff. In the dry season, by contrast, most creeks and rivers become saline for much of their length (Figure 4 ).

In addition to the constraints on locomotion and settlement imposed by this extreme climatic regime, resource availability is also conditioned by seasonal factors. Most coastal resources, particulari sheliflab, were available during the wet and early dry seasons (January to 
a.12,000 b.p. approx.

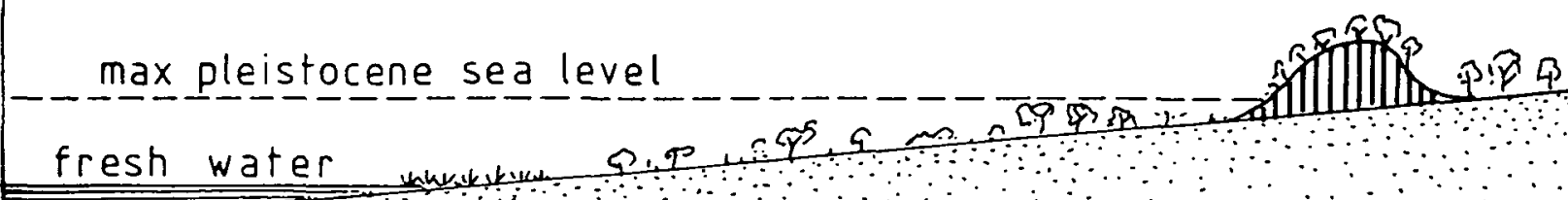

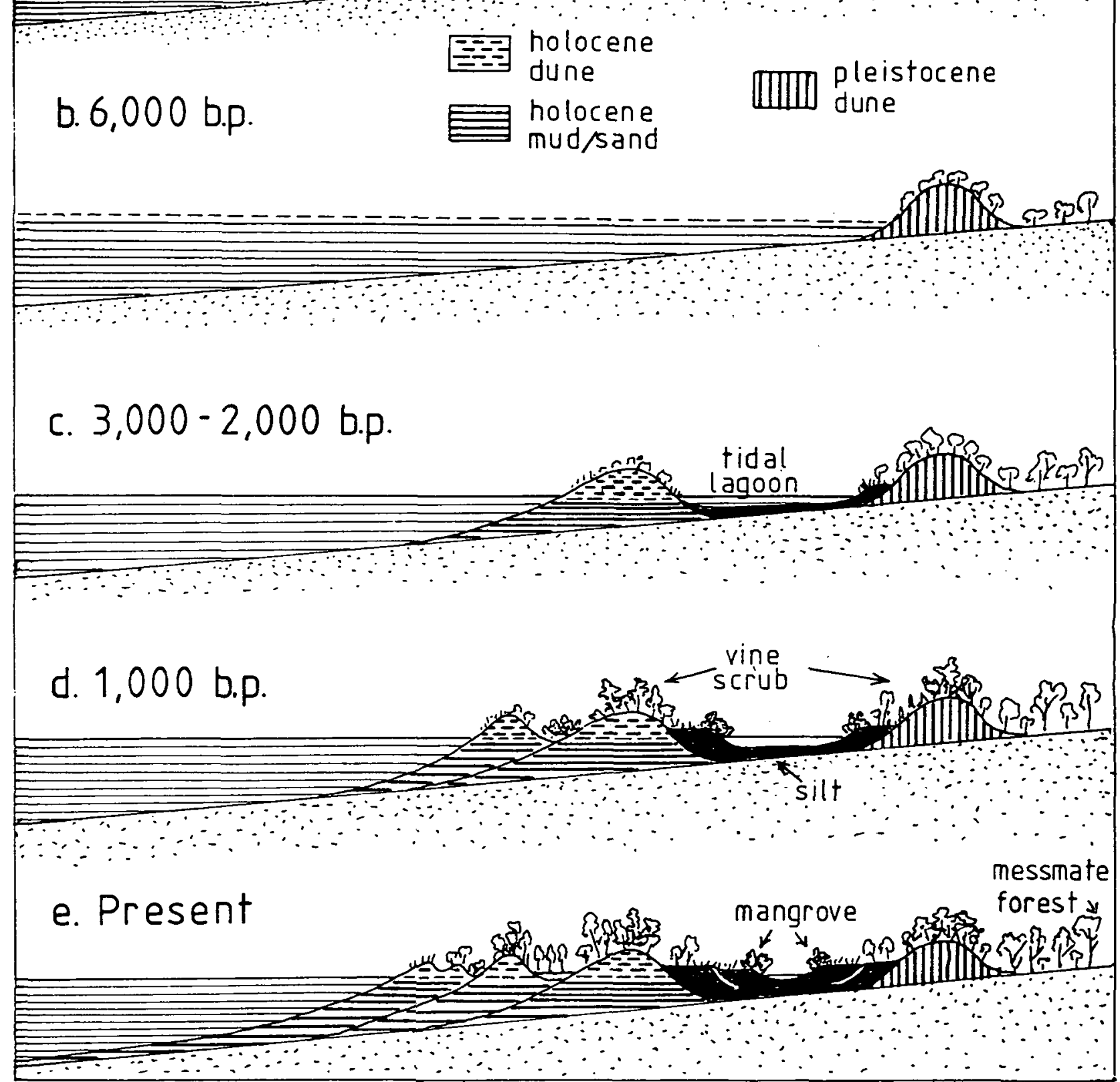

Figure 3. A sequential model of coastal progradation on west Cape York Peninsula.

a. Late Pleistocene $(12,000$ BP approx.) : brackish lake occupies Gulf of Carpentaria.

b. Sea level maximum (6000-5000 BP approx.): Sea level rises to old Pleistocene dune system.

c. Mid Holocene (3000-2000 BP approx.): sand bar and barrier enclosing large tidal lagoon.

d. Late Holocene ( 1000 BP approx.): Infilling of lagoon and further offshore sandspit formation. Mangrove development and coastal progradation through sandspit and delta formation. 


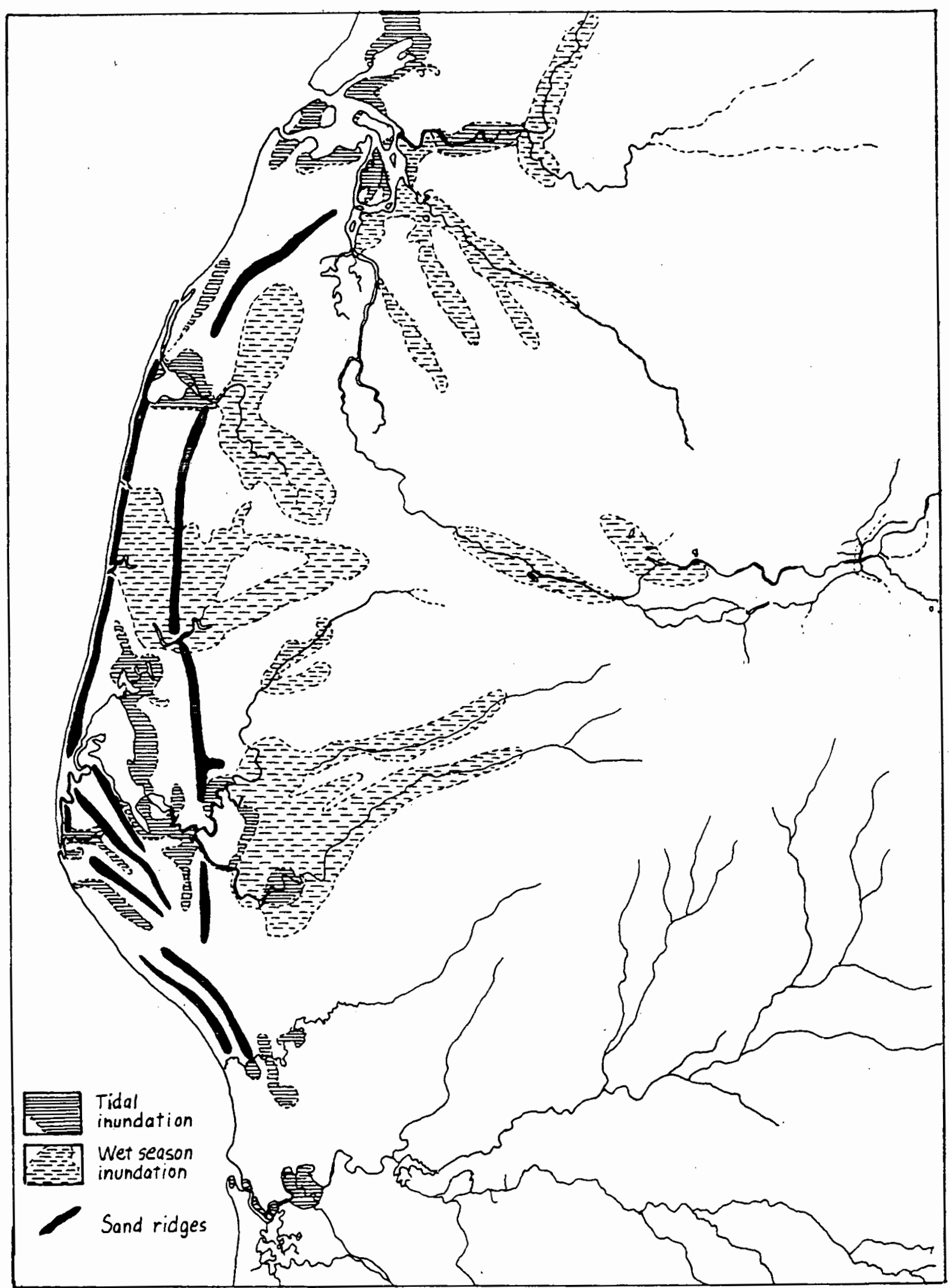

Figure 4. Seasonal and tidal inundation patterns in the Aurukun study area. 
May), while the lagoons and smaller watercourses were exploited in the dryer months and storm times (June to December).

Much has been written about the possible effects of "fire-stick farming" on the post-Pleistocene environment (Jones 1969; Hynes and chase 1982). Today there appears to be no conscious link between the use of fire and productivity of the environment. Access and ease of travel are more important considerations (see also Bailey 1975 ). Environmental changes since depopulation of the traditional areas during the $20 t h$ century is not explained in terms of burning. Instead it is said that if people have been away from an area for too long, the absence of human smel 1 al lows the country to get "full up" with trees and underbrush (sutton 1978:49-50). Sustained presence of humans and human smell will cause it to "go down" again. However, one of the first acts on entering an area choked with dry grass or understorey is to burn it. The prime candidates are inland sclerophyl woodland and open woodland savannah and grassland. It is possible that, through time, this practice has favoured the spread of fire-tolerant species.

In terms of carrying capacity, the mere presence of a coastline as such need not act as a magnet to human settlement. The ocean beach itself offers few resources for the traditional or contemporary inhabitants of the Aurukun area (Sutton 1978). Although turtle and dugong are present offshore and are occasionally taken, the people are essentially land-oriented. Salt water species, particularly barramundi, mud crab and stingray are exploited in the estuaries. Mud shell (Geloina), oysters and whelks are taken from the mangroves. But the seagoing, fishing cultures of Tcrres strait and northern and eastern Cape York, and the out-rigger canoe (Thomson 1939), stop abruptly just north of Aurukun, precisely at that point where the red bauxite-bearing cliffs turn inland off the coast, opening up large tracts of extensive wetlands and dune systems extending south as far as Karumba (Figure 1).

In terms of human exploitation, the richest zone in contemporary times is the silt plain whose swamps and lagoons support a teeming bird life; ibis, jabiru and brolga may be seen in their hundreds stalking across the flats or flocking on the margins of residual swamps. However, the rough nature of this terrain, either hard-baked clay or bottomless mud, together with the lack of shade, renders it unsuitable as a camping place. Saltpan, though lacking resources, is suitable for overnight camps in the dry season. In either case tidal action and seasonal inundation would leave few traces of human occupation. on the open savannah woodland are found plains turkeys and other bird life together with swamp resources but the hard ground and absence of substantial shade also make this an unpopular location for camping. Resources in sclerophyl country are focused on the swamps and stream beds.

The dune systems, both Pleistocene and Holocene, offer by far the most diverse and actractive environment in terms of shade, soft ground for camping, game (wallaby, plains and scrub turkey) and vegetable resources (yams and berries). The majority of campsites, contemporary or remembered, occur on dunes, in open spaces adjacent to vine thickets and within $50 \mathrm{~m}$ of a well (cf. Peterson 1973). The juxtaposition of cleared campsites, often containing evidence of former occupation in the form of middens, and large stands of fruit and shade trees suggests the presence of a form of domiculture similar to that discussed by Hynes and Chase (1982) for eastern Cape York Peninsula. It is possible that the 
attractiveness of the dune complex for human habitation has been enhanced by human settlement itself which, through re-seeding, has resulted in local concentrations of heavily exploited species.

The dune-savannah interface provides abundant water sources. Except in sclerophyl country and around the major lakes and swamps, fresh water is available mainly from wells dug at the edge of dunes where water seepage is trapped by underlying clays (even where open water is available it is usually accessed from wells dug near the edge). In addition to local resources, most of these dune campsites are within easy reach of hunting grounds in neighbouring swamps or lagoons and fishing places in creeks and tidal arms.

The strand complex is quite heavily used both for exploiting marine resources and for day shade camps. Each campsite on a coastal dune has a corresponding beach camp, generally bearing the same name. However, although a significant proportion of the coastal economy is oriented towards marine resources; the "sand beach" people cannot be equated with the seafaring dugong and turtle hunters of eastern Cape York or those on the west coast to the north of Aurukun (Sutton 1978; von Sturmer 1978). The main focus is and was on estuarine and swamp resources such as birds, crabs, stingrays, barramundi and other estuarine fish and shell fish.

Viewed diachronically, while both Pleistocene and Holocene dune systems would have always offered both resources and camping sites, the evolution of silt plains and swamps would have been a slow process and much of the abundant bird life present in the region today would have been absent in the early Holocene. People entering such a coastal environment would have found few of today's resources available. Prior to the development of savannah woodland, silt plains and vegetated coastal dunes the main resources would have been estuarine and mangrove, on the fringes of a vast mid- Holocene lagoon. While certainly not being determined by them, the subsequent history of human settlement in the Aurukun region would have been closely linked to the evolution of these landforms.

THE QUALITY OF THE ARCHAEOLOGICAL EVIDENCE.

There being no rock shelters on western Cape York south of Weipa, most archaeological evidence is in the form of shell middens. As indicated elsewhere (Cribb 1968) the use of shell as a primary indicator of the presence and extent of human settlement is fraught with difficulties. The high archaeological visibility and selective survival of shell can easily distort our inferences about the location and relative density of ancient settlement. In the following account no claims are made as to the prehistoric settlement system of the region, only the classes of archaeological evidence that have so far come to light.

Five main shell species were present. Information on each, obtained from both scientific sources and local informants has been summarized in Table 1 . The presence or absence of these shell types on the sites, together with their environmental context, provide the main criteria for classification. For present purposes, the sites may be divided into four categories: 
1. Thin surface middens located on dunes.

2. Surface middens located on silt.

3. Mounded middens containing a low proportion of shell.

4. Steep-sided shel 1 mounds. These are comparable with examples from Weipa (Bailey 1977), Princess Charlotte Bay (Beaton 1985) and Arnhem Land (Peterson 1973; Meehan 1982).

Altogether 72 sites were located (Figure 5) distributed across the four categories as shown in Table 2a. Table 2 b indicates the breakup according to geological and vegetation zones.

Table 1. Scientific and local names for major shell species identified in the 1985 season, together with behavioural and cultural information (scientific names are of the format "Family: Genus species").

\begin{tabular}{|c|c|c|c|c|c|c|c|c|c|}
\hline $\begin{array}{l}\text { COMMON } \\
\text { NAME }\end{array}$ & I LINNAEAK & $\begin{array}{l}\text { HIK } \\
\text { nUNEKAN }\end{array}$ & $\begin{array}{l}\text { MIK } \\
\text { NGATHAN }\end{array}$ & I EDIBILITY & I HABITAT & BEHAVIOUR & $\begin{array}{c}\text { MODE OF } \\
\text { EXTRACIION }\end{array}$ & I OTHER USES & ; \\
\hline $\begin{array}{l}1 . \\
\text { COCKLE }\end{array}$ & $\begin{array}{l}\text { Archidae: } \\
\text { Inadara } \\
\text { i granosa } \\
\text { ! }\end{array}$ & $\begin{array}{l}\text { Minh Yongkt } \\
\vdots \\
\text { i }\end{array}$ & $\begin{array}{l}\text { : Minh Aaung } \\
: \\
: \\
:\end{array}$ & $\begin{array}{l}\text { "Good to } \\
\text { i eat" } \\
i \\
\end{array}$ & $\begin{array}{l}\text { I Sub-tidal in } \\
\text { ishallow, ouddy } \\
\text { I sands; low wave } \\
\text { ienergy, high } \\
\text { inater flow }\end{array}$ & $\begin{array}{l}\vdots \\
y i \\
\text { ei } \\
\vdots \\
\vdots\end{array}$ & $\begin{array}{l}\text { place in } \\
\text { f fire to } \\
\text { i open } \\
\text { : }\end{array}$ & $\begin{array}{l}\text { i none } \\
: \\
i \\
i \\
i\end{array}$ & i \\
\hline $\begin{array}{c}2 . \\
\text { CONCH }\end{array}$ & $\begin{array}{l}\text { i Helongen-1 } \\
\text { idae: } \\
\text { i Volegala } \\
\text { mardiana } \\
\vdots \\
:\end{array}$ & $\begin{array}{l}\text { Minh } \\
\text { Kunchikul, } \\
\text { Mint Ooynk } \\
\end{array}$ & $\begin{array}{l}\text { : Keren } \\
\text { igeneric) } \\
\text { : Minh lier } \\
\vdots \\
:\end{array}$ & $\begin{array}{l}\text { not eaten } \\
\vdots \\
\vdots \\
\vdots\end{array}$ & $\begin{array}{l}\text { I Hangrove, } \\
\text { inter-tidal } \\
\text { isub-tidal } \\
\text { iqudflats } \\
\vdots \\
:\end{array}$ & $\begin{array}{l}\text { i Highly mobile } \\
\text { iscavenger; } \\
\text { igreat intra- } \\
\text { ispecies var- } \\
\text { i iability, local } \\
\text { ipopulations }\end{array}$ & $\begin{array}{l}\text { : Soash with } \\
\text { istone to re- } \\
\text { iaove flange } \\
\vdots \\
:\end{array}$ & $\begin{array}{l}\text { : bait, } \\
-: \text { large shells } \\
\text { i used as nater } \\
\text { l containers } \\
:\end{array}$ & $\begin{array}{l}i \\
i \\
i \\
i\end{array}$ \\
\hline $\begin{array}{l}3 . \\
\text { MUD } \\
\text { XHE: }\end{array}$ & $\begin{array}{l}\text { Potonididae: } \\
\text { Telescopiua } \\
\text { telescopiua: } \\
\vdots\end{array}$ & $\begin{array}{l}\text { : Hinfoun-ong } \\
\text { : Ulong arsel } \\
\text { : } \\
\text { : }\end{array}$ & $\begin{array}{l}\text { : Minh kunser } \\
\text { liEdward River } \\
: \\
; \\
?\end{array}$ & $\begin{array}{l}\text { "Good to } \\
i \text { est" } \\
i \\
i\end{array}$ & $\begin{array}{l}\text { I Inter-tidal } \\
\text { i sudflats } \\
\text { iangroves } \\
:\end{array}$ & $\begin{array}{l}\text { Gregarious } \\
\text { i herbivore } \\
\text { idetrius feeder } \\
\text { ilon sobility, } \\
\text { i non-seascnal }\end{array}$ & $\begin{array}{l}\text { icook in fire } \\
\text { I \& hit with } \\
\text {, stick to } \\
\text { i remove } \\
\text { I contents }\end{array}$ & $\begin{array}{c}e i \\
\vdots \\
\vdots \\
\vdots\end{array}$ & $i$ \\
\hline $\begin{array}{l}4 . \\
\text { Muvi } \\
\text { Sireli }\end{array}$ & $\begin{array}{l}\text { iveneridae: } \\
\text { l Seloins } \\
\text { : (species } \\
\text { indeterin-t } \\
\text { i ate) }\end{array}$ & 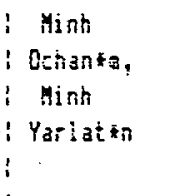 & $\begin{array}{l}\text { : Minh } \\
\text { i Gehanta, } \\
\text { : Kinh } \\
\text { : Kunaal } \\
\text { : }\end{array}$ & $\begin{array}{l}\text { "Good to } \\
\text { : est" } \\
i \\
i\end{array}$ & $\begin{array}{l}\text { i nangrove } \\
\text { inter-iodal } \\
: \\
:\end{array}$ & $\begin{array}{l}i \\
\vdots \\
i \\
i \\
i\end{array}$ & $\begin{array}{l}\text { i flace in } \\
\text { i fire to } \\
\text { i open } \\
\text { : }\end{array}$ & $\begin{array}{l}\text { Scraper for } \\
\text { i saoothing } \\
\text { i spears, string } \\
\text { i Knives } \\
\text { i }\end{array}$ & $\begin{array}{l}\vdots \\
\vdots \\
\vdots\end{array}$ \\
\hline $\begin{array}{l}\text { 5. } \\
\text { MAH- } \\
\text { GHOUE } \\
\text { OYETES }\end{array}$ & $\begin{array}{l}\text { iêstreidae: } \\
\text { iSaccostrea } \\
\text { íspeties } \\
\text { unspertitied } \\
\vdots \\
i\end{array}$ & $\begin{array}{l}\text { int Harta } \\
\vdots \\
i \\
i\end{array}$ & $\begin{array}{lll}1 & \text { Minh Hart } \\
\vdots \\
\vdots \\
\vdots \\
\vdots \\
i & \end{array}$ & $\begin{array}{l}\text { : "Wery good } \\
\text { i to eat" } \\
\vdots \\
\vdots \\
\vdots \\
\vdots\end{array}$ & $\begin{array}{l}\text { Srows in } \\
\text { i clusos on aan? } \\
\text { i grove roots, } \\
\text { inter-tidal } \\
\text { ! to shailo* } \\
\text { i sub-tidai }\end{array}$ & $\begin{array}{c}\vdots \\
\vdots \\
\vdots \\
\vdots \\
\vdots\end{array}$ & $\begin{array}{l}\text { Cut section } \\
\text { isi angrove } \\
\text { iroot, place } \\
\text { ieluap on fir } \\
\text { iturning till } \\
\text { ivalves open }\end{array}$ & $\begin{array}{l}n: \text { none } \\
\text { Ilconsidered too } \\
\text { i sharp is dang- } \\
\text { re erous for cutt } \\
\text { l! ing } \\
\text { i }\end{array}$ & $\begin{array}{c}\vdots \\
0 ! \\
i \\
- \\
\vdots \\
\vdots\end{array}$ \\
\hline $\begin{array}{l}\text { b. } \\
\text { BLACK } \\
\text { LiF }\end{array}$ & $\begin{array}{l}\text { iAnoajidae: } \\
\text { if!acuna } \\
\text { iplacenta } \\
\text { i }\end{array}$ & : Oeng̣keth & $\begin{array}{l}\text { i Pathtih } \\
\vdots \\
\vdots\end{array}$ & 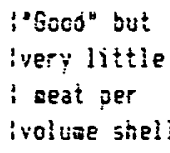 & $\begin{array}{l}\text { : Abundiant in } \\
\text { Eub-tidal, } \\
\text { i shallou } \\
\text { 1 iaṣoons }\end{array}$ & $\begin{array}{c}\vdots \\
\vdots \\
\vdots\end{array}$ & $\begin{array}{l}\text { i Coot on } \\
\text { i fire } \\
\text { : }\end{array}$ & $\begin{array}{l}: \text { none } \\
\vdots \\
\vdots \\
i\end{array}$ & $\begin{array}{l}: \\
\vdots \\
\vdots\end{array}$ \\
\hline
\end{tabular}




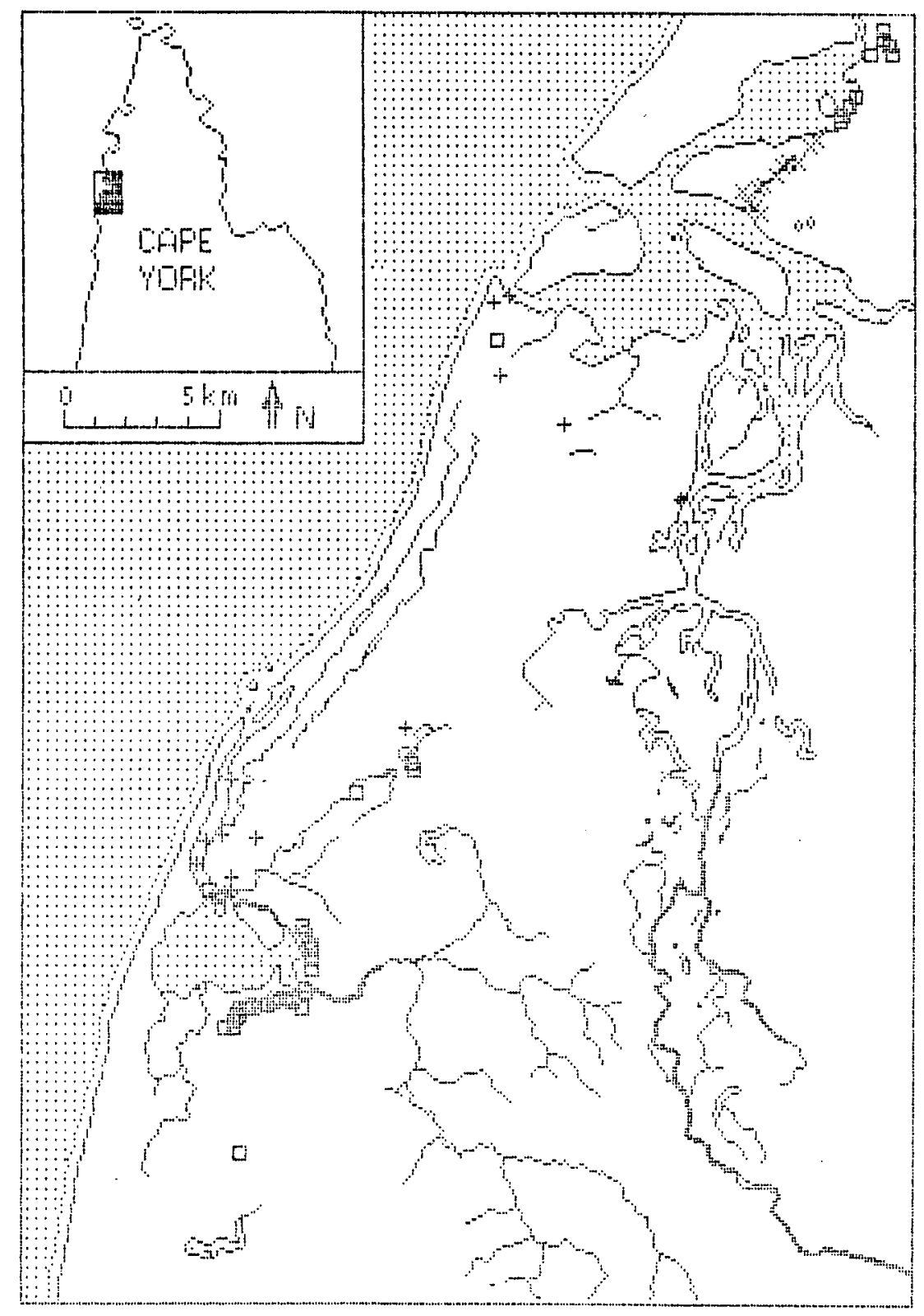

$x$ pleist + dune [] silt o salt pan * other

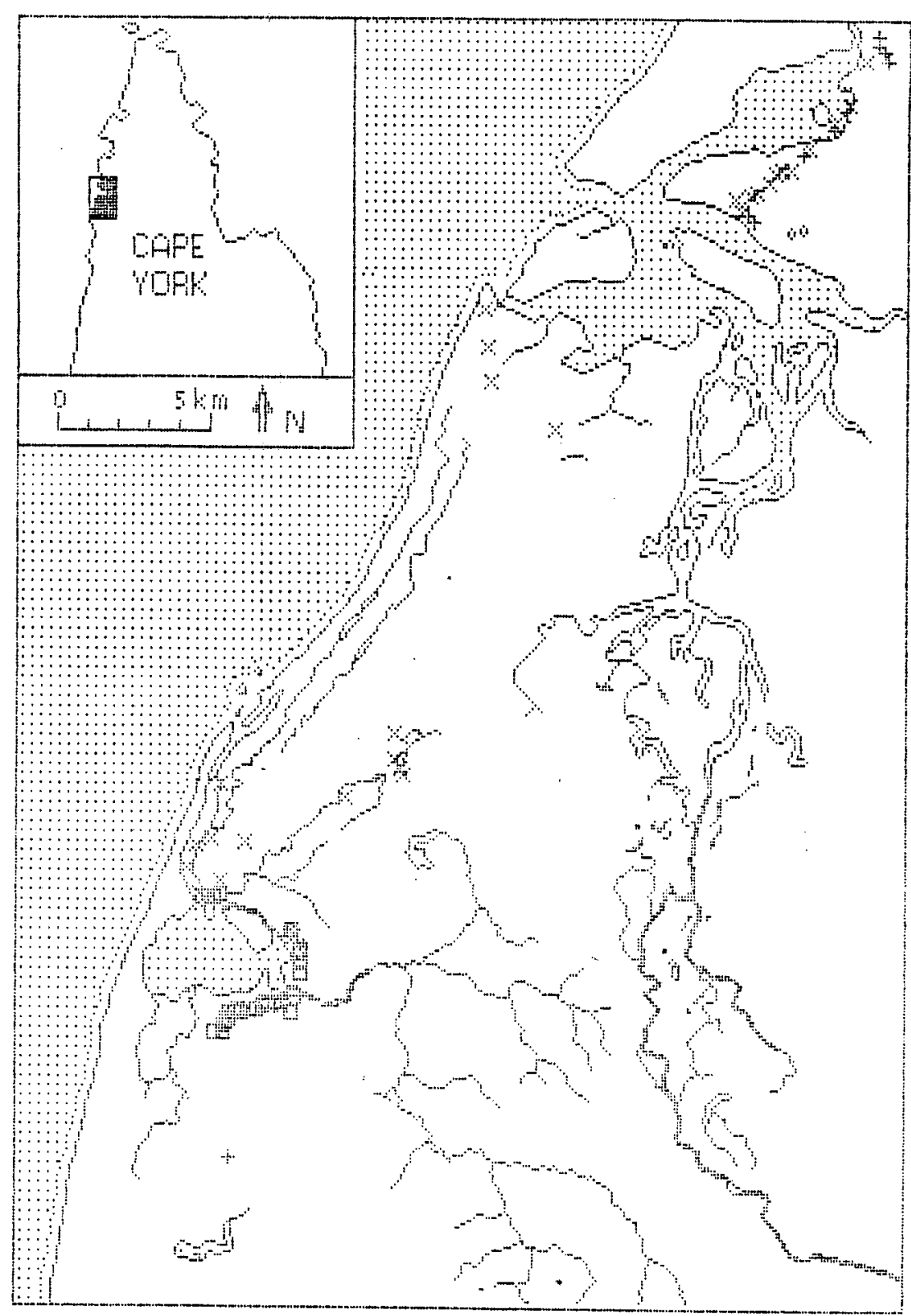

$x$ aidden + ound [] she!l wound 0 other

Figure 5. Distribution of archaeological sites located during 1985 by environmental/geological zone and according to site type. 
Table 2a. Frequency of occurrence of archaeological sites by site type.

\begin{tabular}{lcc} 
& NO. OF \\
SITE CATEGORY & SITES & 8 \\
\hline 1. Surface midden on Dune & 22 & 38.8 \\
2. Surface midden on Silt & 11 & 16.4 \\
3. Mounded midden & 5 & 7.4 \\
4. Shell mound & 28 & 41.8 \\
Other & 1 & 1.5
\end{tabular}

Table 2b. Frequency of occurrence of archaeological sites by plant community.

\begin{tabular}{lcc} 
& NO. OF \\
SITES & 8 \\
1. Holocene Dune & 20 & 29.4 \\
2. Pleistocene Dune & 8 & 11.8 \\
3. Silt & 37 & 54.4 \\
4. Saltpan & 2 & 2.9 \\
5. River sand & 1 & 1.5 \\
\hline
\end{tabular}

As the main purpose of the 1985 project was ethnographic mapping, archaeological sites were located piecemeal rather than through systematic archaeological survey. It cannot therefore be claimed that this distribution is representative of the area as a whole. The impetus of an ethnographic mapping trip is not really conducive to detailed archaeological recording as the chief priority is getting from one site to the next in the shortest possible time. However on the two occasions when specifically archaeological trips were carried out, estate owners or affiliates were positive in offering help in site recording and shell identification. Some of the mounds in particular were also story places on which certain rules of etiquette had to be observed. These restrictions were more likely to be invoked when accompanied by those who were not full custodians than by core custodians.

Some of the sites, particularly the middens located on dunes were more in the nature of continuous scatters with areas of high concentration. These in turn need to be distinguished from natural shell incorporated into the dunes in the course of their formation. The latter occurrences are far greater in extent and depth and are marked by an absence of other cultural material and the presence of a full range of shell sizes skewed towards the very small end of the spectrum (Bailey 1977). I will now deal with the sites according to the geographical units in which they were discovered (Table 3 ).

THE LOVE RIVER SHELL MOUNDS

These are true shell mounds ranging in height from degraded remnants less than half a metre high to large eminences over three metres in height. Twenty five such sites were recorded (including non-mounded 
Table 3. Presence/absence of marine shellfish species on sites surveyed in 1985.

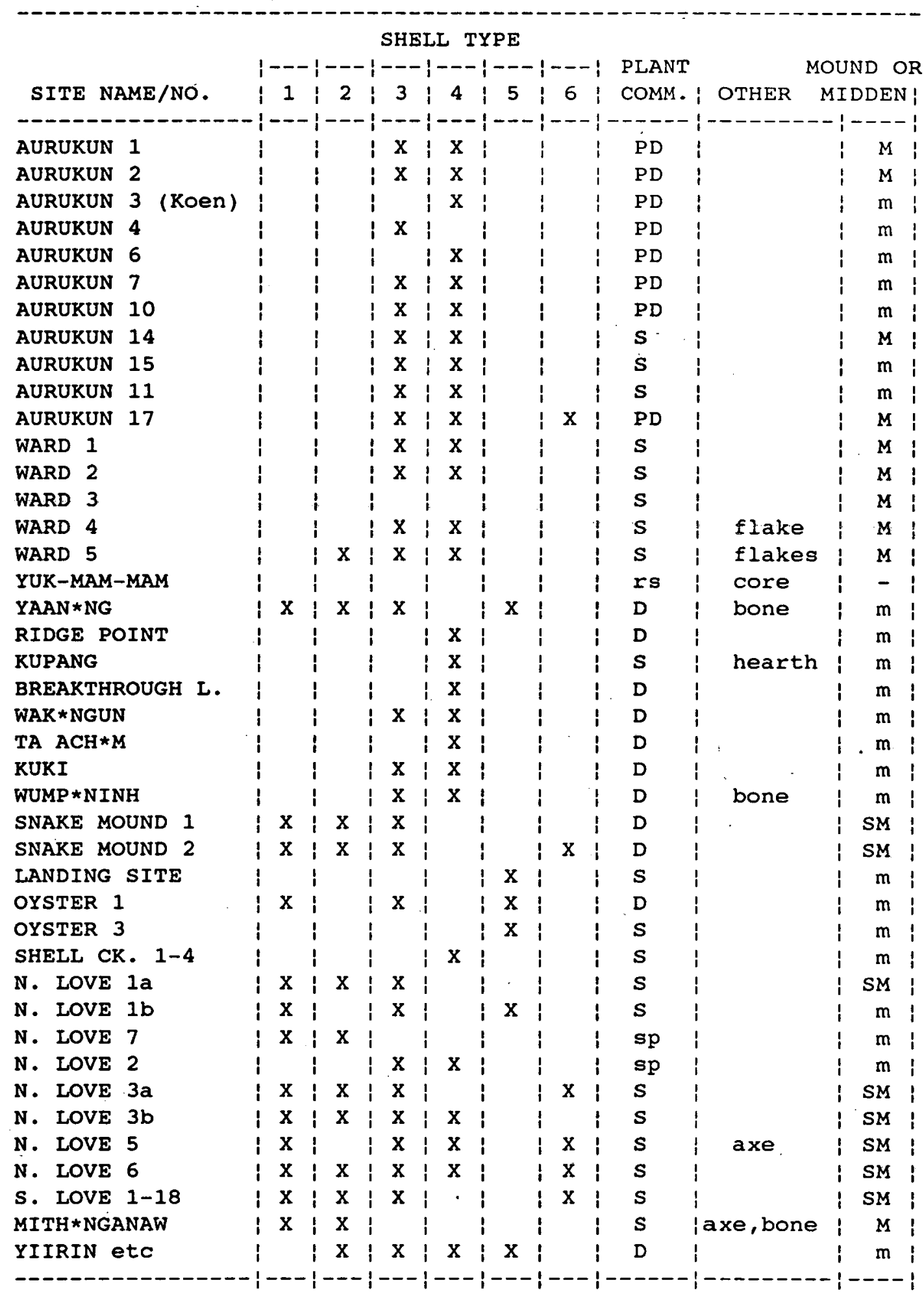

\section{Anadara granosa 2.volegalea wardiana 3.Telescopium telescopium 4. Geloina

$P D=$ Pleistocene dune $D=$ other dune $\quad \mathrm{S}=$ silt $\mathrm{m}=$ midden sp $=$ salt pan $M=$ mound $S M=$ shell mound $r s=$ river sand 
deposits) both north and south of the Love River Estuary in a Ine following the edge of the silt plain where it borders on salt pan, normally within close walking distance of mangroves. While none was as massive as some of the Weipa shell mounds the conclusion reached by Bailey (1975), that shell mounds do not occur south of weipa, must now be revised.

The mounds contained four main shell types, by far the most numerous being cockles (Anadara granosa) (roughly 99\%) together with isolated conches (Volegalea wardiana), mud whelks (Telescopium telescopium) and black lips (Placuna placenta). While the mud shells (Veneridae) are by far the most heavily exploited today, they were generally absent, found only at the edges of some of the mounds and may represent relatively recent occupation events. There was some uncertainty concerning the overwhelming presence of Anadara granosa. The species is not heavily exploited today, and most informants insisted that it was obtained only from the ocean beach, some $3 \mathrm{~km}$ distant. Others suggested that some might be found in the Love River estuary, but could not recall having obtained any from there. Most agreed that the species requires a sandy habitat (see also Beaton 1985) while the contemporary Love estuary is largely mudbanks fringed with mangrove.

The optimal habitat for $\underline{A}$ granosa is muddy flats with a high sand content, in a low wave energy environment with a high rate of water flow. The species is prone to extreme abundance under favorable conditions (Wilson and Gillet 1971; Gowlett-Holmes pers comm). It is possible that the Anadara mounds were formed at a time when conditions in the estuary were very different from those pertaining today.

The contents of the conch shell, usually hermit crabs, are not regarded as edible by contemporary people and are used mainly as bait. However, nearly all of the conch shells on mounds had a section of flange removed in order to get at the contents. Those mud whelks not taken over by hermit crabs are highly regarded as food. I was initially curious as to why the tightly spiralled shells were mostly intact, not having been smashed to remove the flesh, but was informed that they were simply heated over a fire then tapped lightly with a stick to remove the contents (cf. Meehan 1982).

While none of the mounds was regarded as a camping place within remembered time, the local people were in no doubt as to their origins - "Those two girls made them". Long ago there were Two sisters who lived a reclusive life, hunting and fishing for themselves, like men, and spearing any unfortunate male rash enough to interfere with them (McConnel 1957:121). The mounds represent their camping places as they tracked northwards around the Love River estuary.

In stratigraphic terms, the mounds were located on a silt substrate (see Figure 6). From surface evidence alone the internal stratigraphy is not entirely amorphous. There was some evidence of horizontal bedding though it is arguable whether this is more pronounced than for the Princess Charlotte Bay shell mounds (Beaton 1985). As the current expedition was not geared for detailed archaeological work it was not possible to pursue this question. Moreover it is uncertain whether even limited excavation or core sampling will be permitted on any of the mounds. On the basis of existing information however, the following is certain. The Love River shell mounds are located on heavy, cracking 
clays, at the edge of salt pan accessible to an estuarine environment. Their formation postdates the initial laying down of silt plains during the mid Holocene, but predates the laying down of the most recent upper sediments and the intrusion of areas of salt pan associated with the meandering arms of recently prograded deltas.

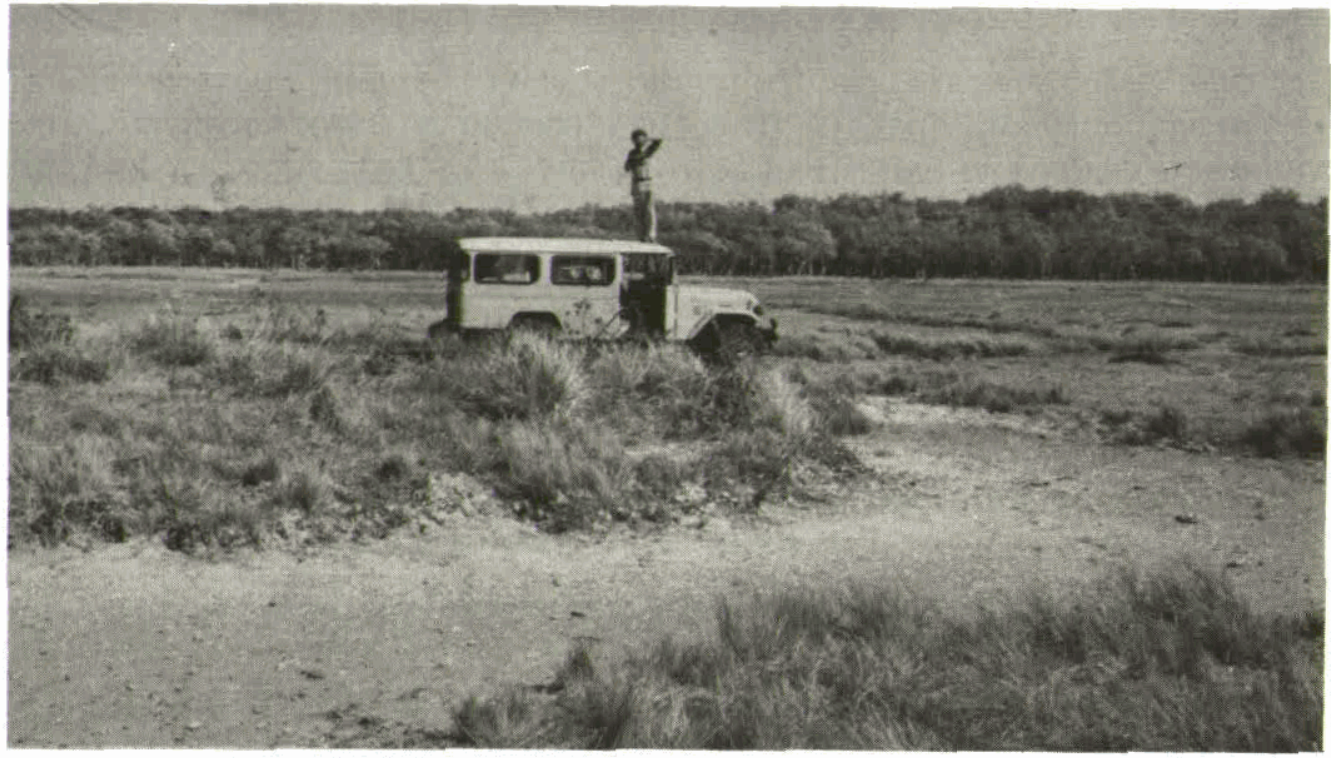

Figure 6. South Love shell mound SL-3. This is an incipient mound now undergoing erosion at the edge of the silt plain. Lenses of shell occur within the silt substrate.

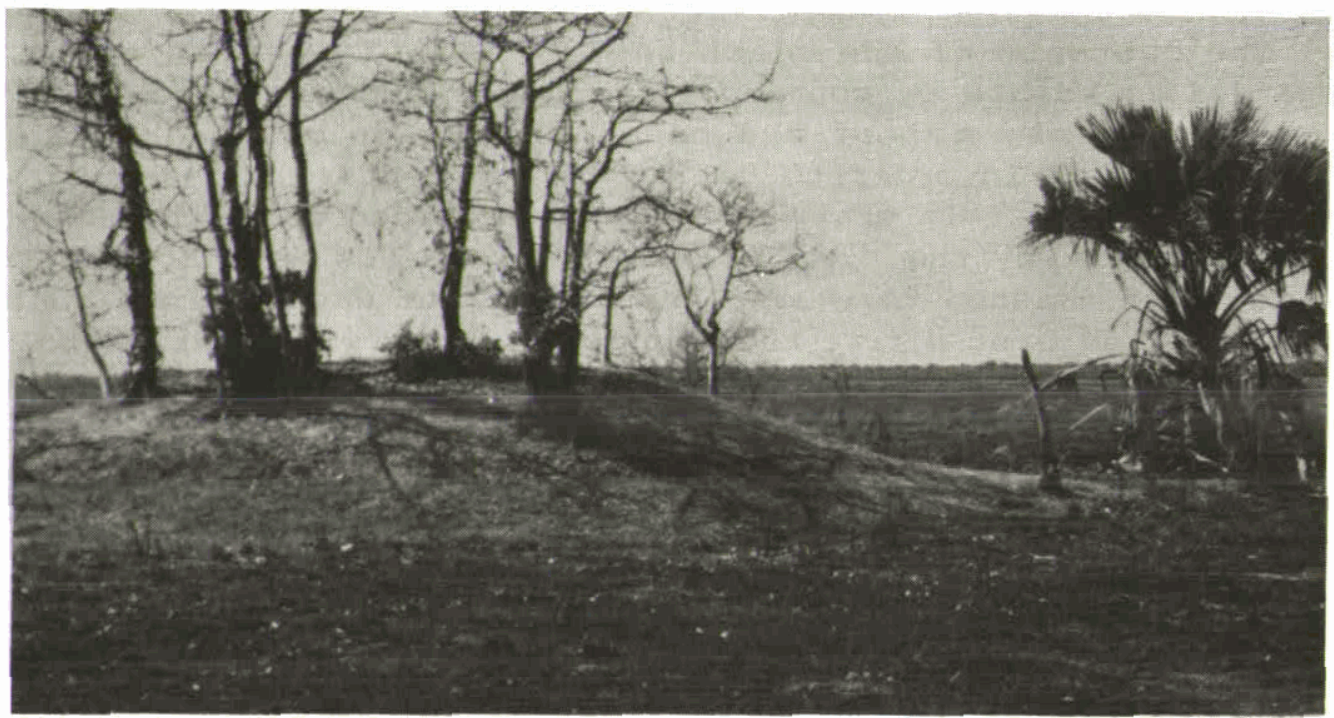

Figure 7. A typical Love River shell mound, SL-9. Note the presence of vegetation typical of dune complexes and the large fan palm nearby .

The only anomalous case is mound NL-6 located directly on saltpan or a basal silt lens only a few metres from the present river bank (Figure 8b). This juxtaposition is probably a recent phenomenon resulting from the northward extension of a meandering arm of the Love River which has eroded the silt plain to the south of the Mound NL-5. Another unusual situation is Mound $\mathrm{NL}-1$, which rests on a small island of silt 
surrounded by salt arms, again the result of recent intrusions of salt pan (Figure 8a). In a few cases (Nos. 2 \& 7) mounds have been entirely removed by this process, leaving only deflated shell scatters directly on salt pan and on the margins of some extant mounds this process may still be observed.

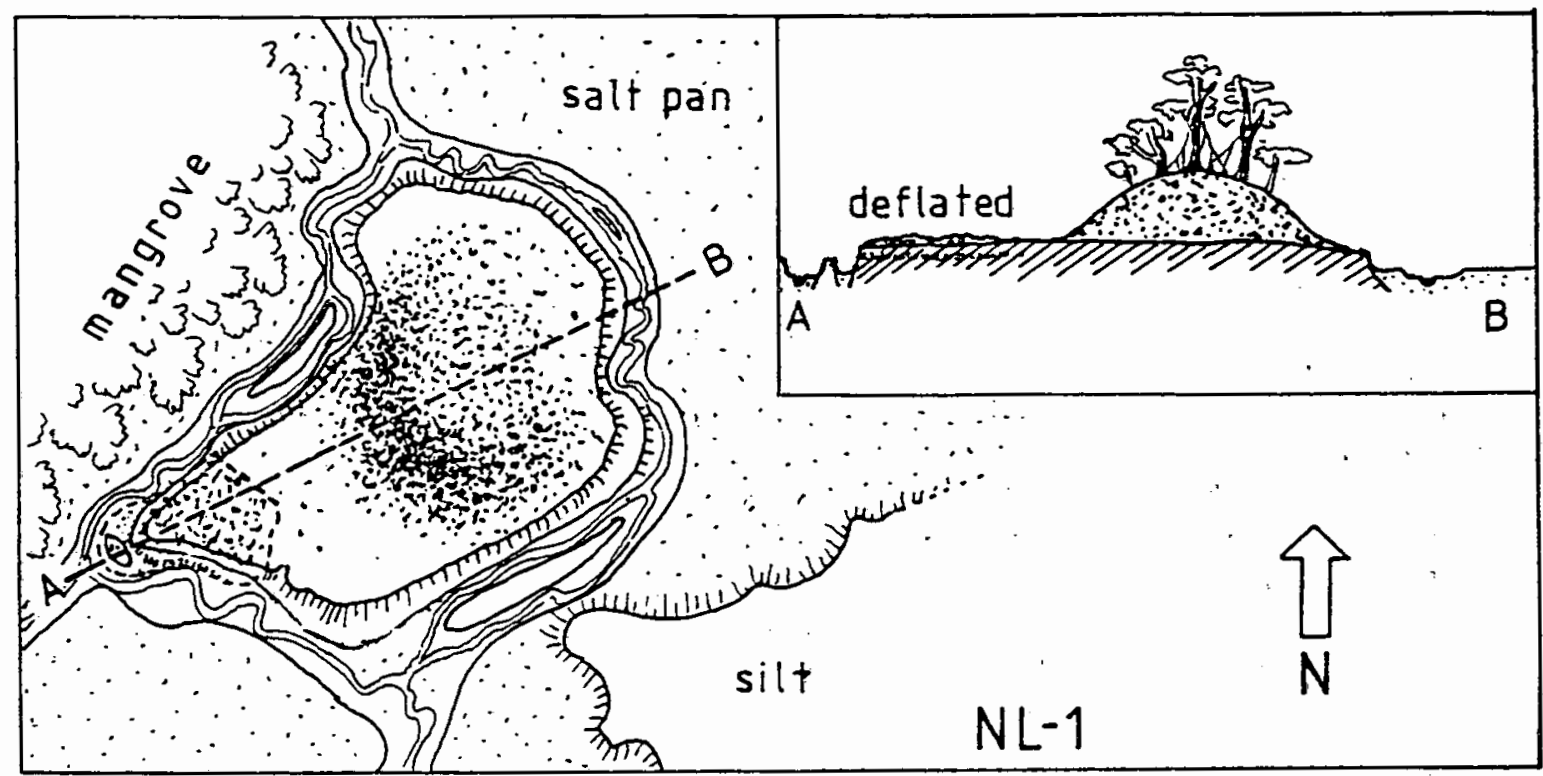

a

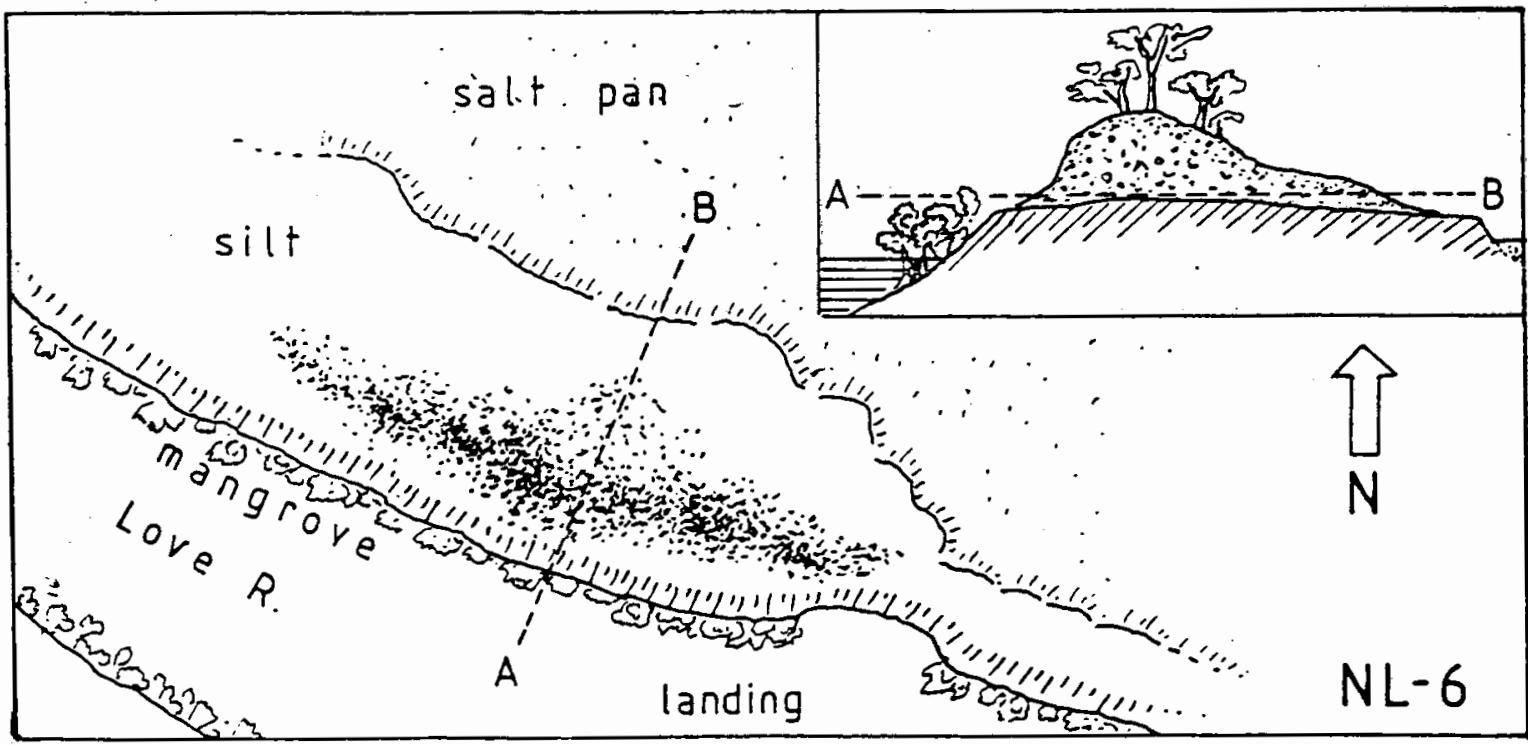

b.

Figure 8. Plan of North Love shell mounds. a) NL-1 - note wide extent of midden material - b) NL-6 - note elongation of platforms. 
On an otherwise treeless plain the first indication that a mound was present was usually the characteristic clump of trees or bushes. Moreover the plants were of a type not. normally associated with silt, even in the higher areas of savannah woodland. All appear to be members of that plant community normaliy found on dune systems, the calcium and silicon from decomposing shell providing an environment similar to the sand ridges. Whatever the agency by which the seeds originally appeared on the mounds, and this could have been natural, the mounds provided a habitat conducive to the establishment of certain members of the dune community (cf. Meehan 1982).

The presence of trees offers a further ciue as to the initial formation and subsequent aggradation of the mounds. The use of silt margins as temporary consumption sites for shell fish is not unknown today but the concentration of debris at a certain locus requires additional explanation. In an area where shade is.considered a primary resource any initial accumulation of shel l sufficient to promote the growth of trees or shrubs would have acted as a magnet to further human occupation. The process may be envisaged in terms of a simple feedback loop: initial shell accumulation, followed by tree growth acting as a focus for further human occupation, continued deposition of shell and so on. The presence of platforms and foothilis on some of the mounds may represent the migration of shade patterns across the site as individual trees flourished, died and decayed to be replaced by others in new locations (see Figure 9 ).

The explanation for the Arnhem Land and Weipa shell mounds offered by Peterson (1973), and supported by Bailey (1975), that aggrading mounds offered dry camping places during wet season exploitation of shellfish, and a welcome escape from insect life, is inadequate. Certainly the mounds, once formed, would have provided a comfortable resting place above the level of sodden clay in the wet and a most inhospitable surface in the dry (Peterson 1973). However this is an expost-facto explanation which fails to account for the initial buildup of deposit, before a platform of sufficient height to provide relief from dampness was formed. The presence of trees on incipient mounds may have been just such a mechanism. In addition to providing shade they woild have facilitated the setting up of temporary lean-tos for shelter from rain; such as those observed by Roth (1901). The location of living and food preparation areas adjacent to trees on the top of shell mounds has been documented by Peterson (1973: 187).

It is uncertain whether these sites represented base camps or overnight camps, as opposed to temporary exploitation, processing and possibly consumption sites. The absence of fresh water and abundant firewood would be an important obstacle to any extended stay. A foraging party leaving at sunrise from one of the main sandridge camps could have reached the mangroves in less than an hour's brisk walk, carrying water in large conch sherls, collected a few days' supply of shell fish, roasted them and extracted the meat over a small fire and returned before the heat of the afternoon. Alternatively they may have rested in the shade at the top of a mound after consuming some of the day's takings, returning with the remainder to the main camp before nightfall. Precisely this pattern has been observed today with mudshells and whelks ( $P$. Sutton, South Australian Museum, pers. comm.). One large stone axe and a single small quartz core were found at one of the mounds, NL-3, though it.is uncertain whether these would have been directly involved in processing the shellfish. 


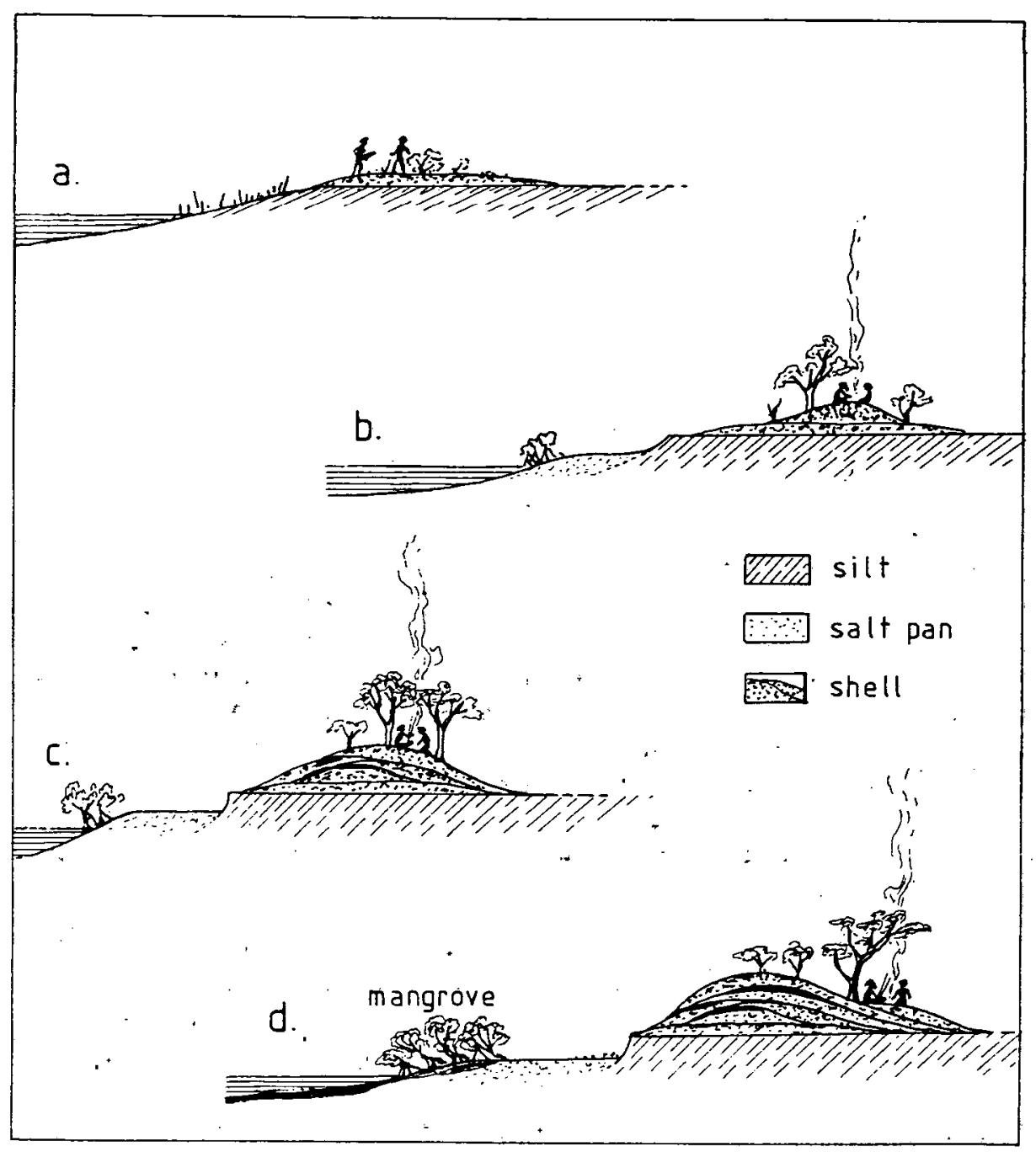

Figure 9. An hypothetical sequence in the evolution of a shell mound: a) initial use; b) initial accumulation and vegetation growth; c) continued siltation and accumulation, formation of salt pan and mangrove; d) further accumulation following shade patterns, erosion of silt plains and mangrove development.

Near the north bank of Love River, on a small arm of shel I creek, two further shell mounds were located. These contained the same shell species as those described above and in much the same proportions. They differed from those further east in that they were located on the margins of an early Holocene dune system and were elongated rather than circular and devoid of vegetation. They differed also in terms of the local account of their origins, being formed not by the "Two Girls" but by the writhings of two huge carpet snakes. These moved from the north east along shell creek and around the base of the dune system where it meets the Love River and up colin Creek, before coming to rest at a spot about half way along the latter (see McConnel 1957:137). In the course of their meanderings, the motion of the snakes coils scoured the shell from underground and heaved it up into the elongated mounds. A fair fascimile of the path followed by the snakes is provided by the meandering courses of Shell and Colin Creeks (see Figure 4). 
Many questions remain to be asked about the Love River shell mounds, principally their age. It is possible that they cover a similar time span as the weipa shell mounds, from 1200 BP to 200 BP. Whether they were the product of a single episode of intensive exploitation comprising a few centuries at most, or whether their formation has been a more continuous process is still far from certain.

\section{MITHANGANAW}

This was one of the few mound sites to beár a name and is so far unique both in terms of its location and general conformation. The surrounding area appears to be part of a degraded Pleistocene dune system now occupied mainly by relatively dense savannah woodland. The presence of an adjacent vine thicket suggests a relict dune fragment and the mound itself may have been of this material. The significance of the mound was initially lost on our party in the wake of the spectacular demise of a large wild boar caught napping in the thicket. Only then was it realized that the mound, initially mistaken for a scrub turkey nest, contained a sizable shell component, and much the same range of species as were present on the shell mounds. A small basalt axe head was located directly on top of the mound and it was decided, in consultation with the estate owners to remove this to Aurukun for safe keeping (these items, together with other artifacts collected in the course of mapping trips, now form the nucleus of a display in the Aurukun Shire Council office).

The mound, over $1 \mathrm{~m} \mathrm{high,} 30 \mathrm{~m}$ across and flat on top, was composed of very black sand and silt, possibly heavily carbonized, with shell concentrations of varying density. It may in fact be similar to the earth mounds observed in Arnhem Land (Peterson 1973) and South Eastern Australia (MacPherson 1884; Williams 1985). There was some speculation that low depressions on the surface filled with dark soil containing fragments of bone may have been the result of cremations but it was felt prudent by all not to pursue this line of investigation further, cremation grounds being considered extremely sensitive places.

In terms of contemporary knowledge, little was known about the place other than the estate on which it was located and the possibility that it might have been a wet season camping spot due to its elevation above the surrounding woodland. The site is located at least $2 \mathrm{~km}$ from the nearest mangrove arm and some $5.5 \mathrm{~km}$ from both the ocean beach and the Love River estuary, the nearest contemporary sources of the Anadara shell predominant on the surface. The site represents one of the few examples south of Aurukun of shell concentrations on a Pleistocene dune or remnant. If the model of coastal progradation outlined earlier is correct, we would expect the site to have been within a short distance of marine resources at some time during the mid-Holocene (thus, it could be of considerable antiquity). Alternatively it may have been a base camp to which remaining shells were brought after initial consumption at one of the shell mounds.

\section{SHELL MIDDENS}

Where the Love River bisects the second line of Holocene dunes, just west of the snake mounds, a line of middens containing predominantly oysters but also scattered cockles and mud whelks occurs in an 
almost continuous distribution along the river bank. Also present were layers of compacted sand containing a high proportion of natural shell. In the course of our own lunch time camp, I was able to observe a small midden site in the process of formation (Figure 10).

On the upper reaches of shell creek were found small surface concentrations of mud shell. Those present on the mapping expedition were able to remember having made similar camps in the past. The shells would have been available in the mangroves of shell Creek itself.

Along the Holocene ridge system north of the Love River were found many surface scatters of shell, mostly mud shell and mud whelks, all of which would have been available from the mangrove arms of shell creek and Colin Creek. It was not possible to attempt to define the extent of these distributions, nor to ascertain their depth. As indicated in Table 3 there was a marked absence of cockle and conches, which fits well with what is known of the sandy, estuarine habitats of these species. The best defined middens occurred on the easternmost Holocene ridge north of the nearest mangrove arms of Shell Creek.

Along the lower reaches of the Love River estuary occurred a series of middens, all located on or adjacent to named campsites, containing mainly mangrove oysters, whose sources are to be found in patches of mangrove along the riverbank, together with smaller quantities of mud whelks and conches. One large midden or series of middens extended for a distance of some $200 \mathrm{~m}$ along the western bank of the Love River located on top of shell grit strata clearly revealed in a steep escarpment some $4 \mathrm{~m}$ high at its maximum, the shell-bearing strata being confined to the top one metre.

It is perhaps worth mentioning here that there appeared to be something of a taboo in operation against the consumption of shellfish by younger people. According to our informants, shellfish from sources to the west of the main ridge system, but not those from shell Creek further to the east, could be eaten only by older men, otherwise the person's hair would turn grey overnight.

\section{AURUKUN MOUNDS AND MIDDENS}

A number of mounds were located north and west of Aurukun settlement. However these mounds were of a different character from the Love River examples. Some were no more than a slightly raised clay platform or flattened dome about half a metre high which may or may not contain an overlay of shell midden. These sites were similar to those described at Castlereagh Bay in the Northern Territory (Peterson 1973:178-9) and the "oven mounds" of the south east (MacPherson 1884:49-50; Williams $1985)$.

Where the red bauxite escarpment comes down almost to the river estuaries, a line of dunes follows the escarpment around the point and up the eastern shore of the Ward River estuary. This appeared to be a continuation of the main Pleistocene dune system interrupted to the south by the course of the Archer River. Two large mounds with a high concentration of shell occurred on the dune line immediately west of the new Aurukun airstrip, just above the mangroves of the Archer River (Figure 11). The mounds were surrounded by smaller middens and hearths, 


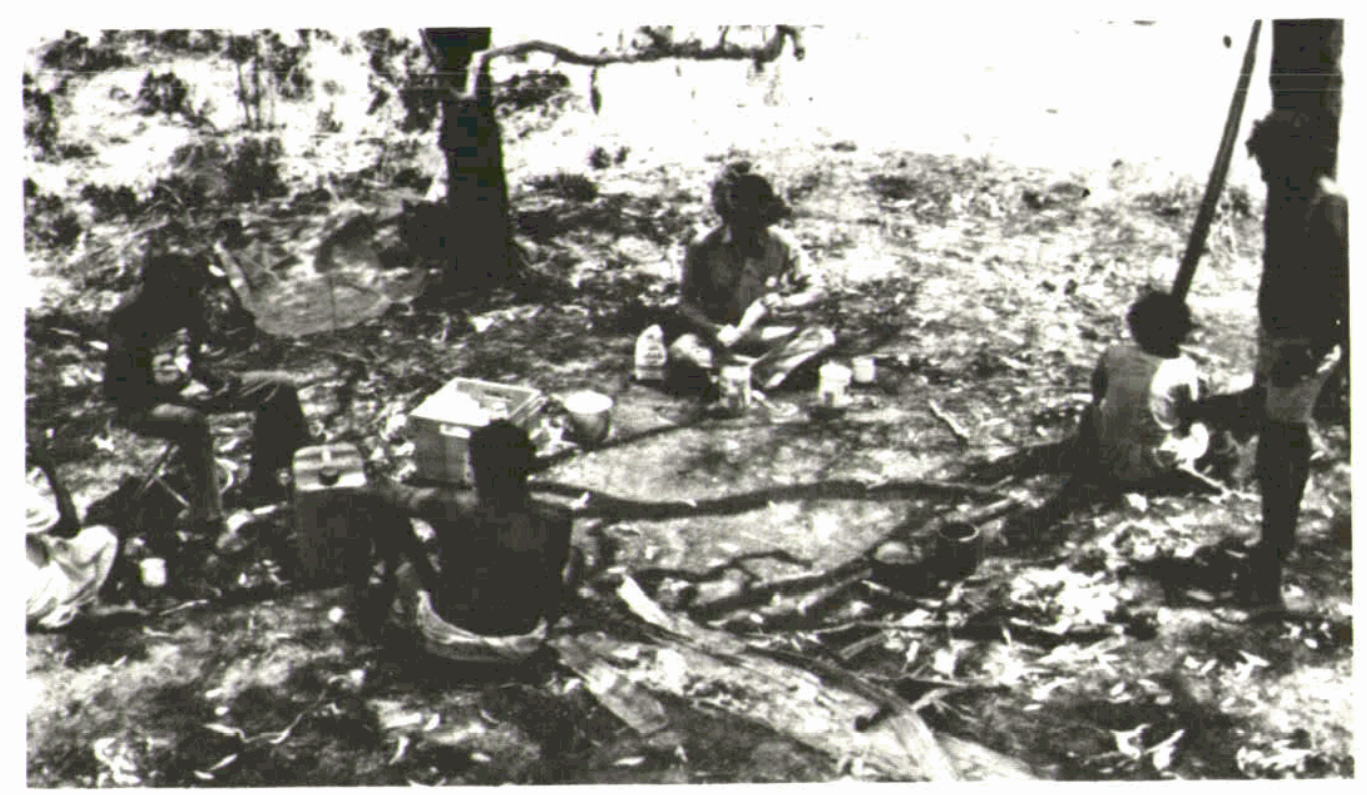

a.

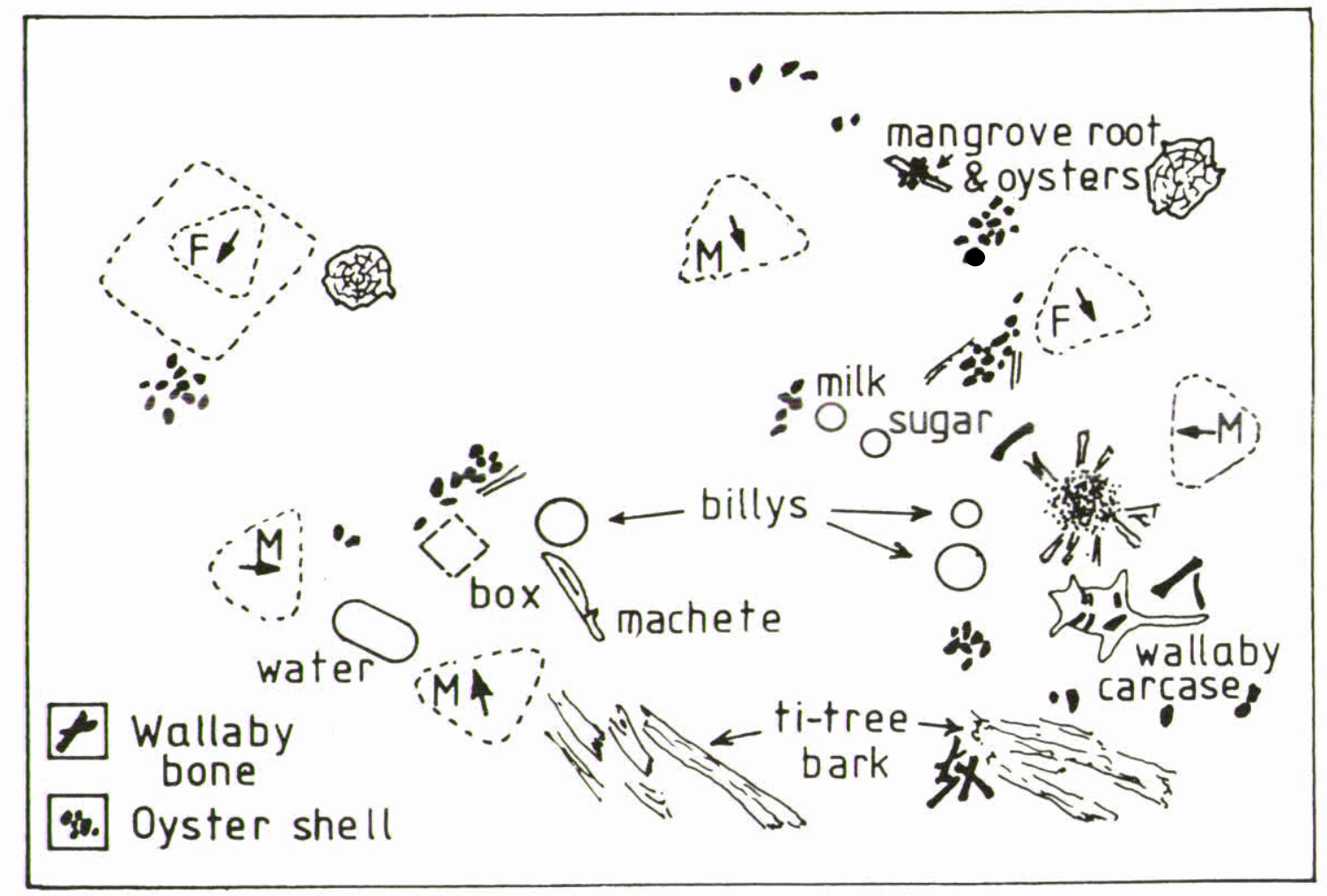

b.

Figure 10. A transitory lunch time oyster camp. a) during meal note spacing of individuals and location of hearths. b) plan of area after abandonment. 


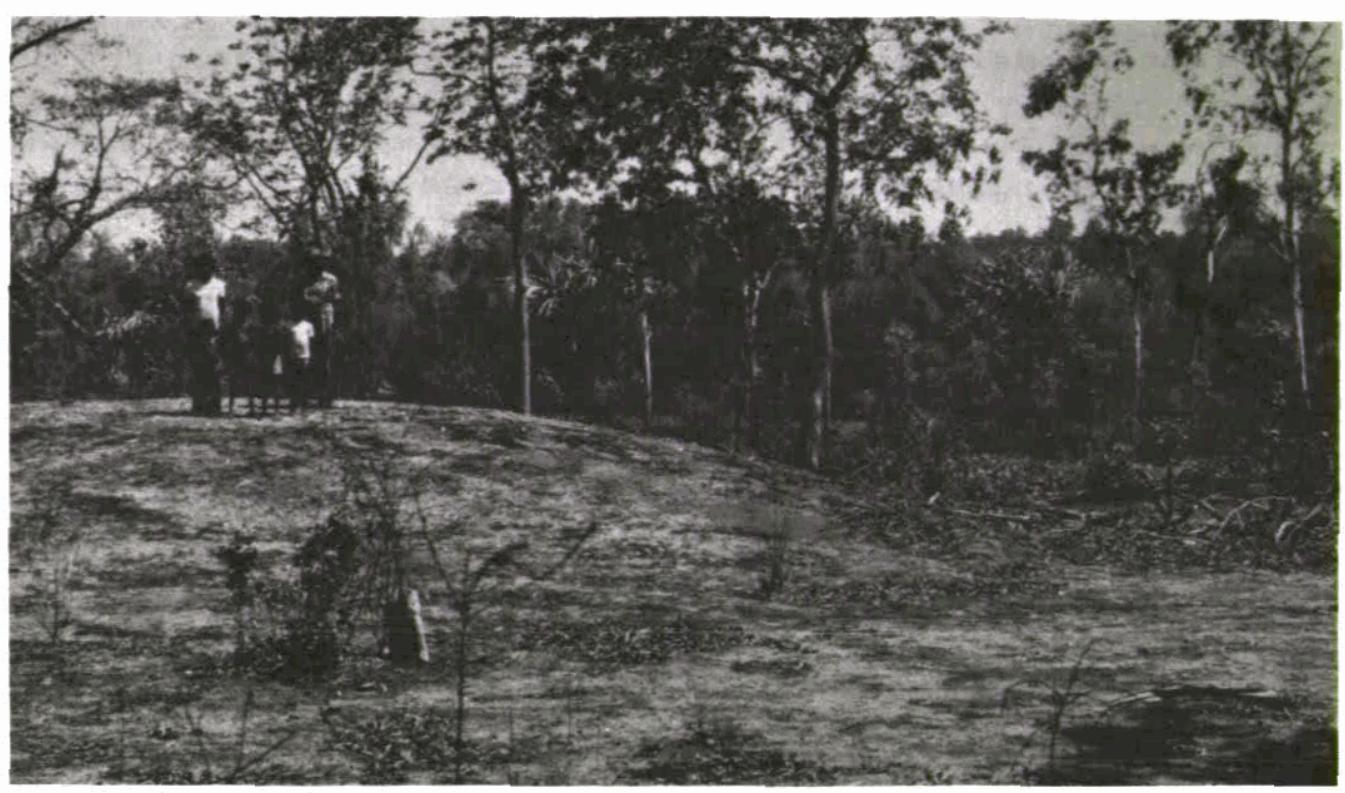

Figure 11. Example of a mounded midden. This is AK-2 on the north bank of the Archer River. Shell is interspersed with a matrix of silt and sand.

some of which represented quite recent events. Mud shell and mud whelks were present but no conch or cockle. Sites consisting mainly of mud shell and mud whelks continued along the sand ridge system to the north, though now mainly in the form of middens or degraded mounds atop the sand ridge. A bower bird cache adjacent to one of the middens contained much the same range of shell types and sizes as occurred on the middens, its only distinguishing feature being a much denser concentration of shell.

Further north still, the sand ridge disappears but midden sites, earth mounds and isolated dune thickets continue close to the salt pan and mangrove arms. It is possible that these locations follow the path of a degraded Pleistocene ridge, whose trace elements have been leached downwards into underlying silts thereby supporting elements of the dune scrub plant community.

The most northerly sites were also linked to the Two Girls story mentioned in connection with the Love River shell mounds. Most of these were little more than slight rises above the silt plain, some with no visible shell on the surface. These were said to be temporary campsites of the Two Girls: "They stop here. They say 'no, we go on'." The most northerly site of all, where they finally settled down, was a huge mound some $4 \mathrm{~m}$ in height. Unlike the Love River mounds it was not composed almost entirely of shell; in fact very little shell appeared on the surface except in the back dirt from rat or bandicoot burrows. Dense concentrations of shell were to be found in sub-surface layers in certain areas of the mound and the edges of this midden deposit were quite well defined, above the sterile silt substrate (Figure 12). This midden portion, about $3 \mathrm{~m}$ in height and $33 \mathrm{~m}$ in diameter, apparently rests on a raised silt platform itself about $1 \mathrm{~m}$ in height and over $50 \mathrm{~m}$ in diameter. It is possible that the non midden portion is in fact a large earth mound on which midden has later accumulated. In terms of shell 
species composition the same range occurred as on the other Aurukun mounds, namely mud shell (Geloina) and mud whelk ( $\mathrm{Te}$ lescopium). The sources of these species are currently some $0.5 \mathrm{~km}$ to the west along the mangroves fringing the Ward River, across a broad salt pan.

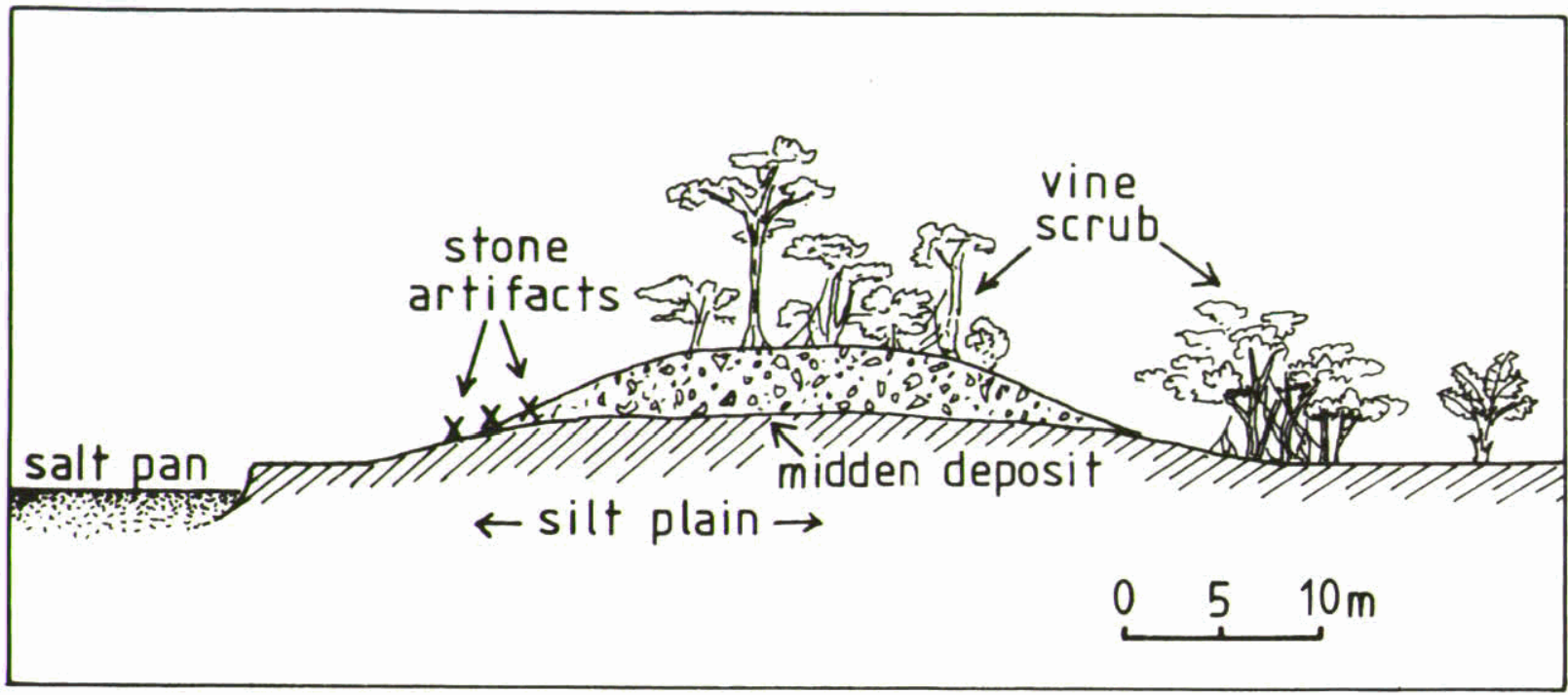

Figure 12. Section drawing of Ward River mound, WARD-5, showing midden portion and non-midden silt substrate.

The mound was surmounted by trees and shrubs belonging to the dune scrub community and a dense vine thicket occurred on the flanks of the mound immediately to the east. This suggests that the mound was originally formed on a relict or degraded dune system. A large fan palm and pandanus occurred at the southern edge of the mound.

This was the only site discovered in the course of the 1985 season with evidence of an extensive flaked stone assemblage. Worked stone in the form of a large core and scattered flakes was found only on the lower north and north west slopes. All of the material was a kind of iron stone no doubt associated with the bauxite complex. A large slab of this material, together with unworked nodules was also found on the northern flanks. It was not possible to remove any of this material for further study. As the site is a story place and none of the key custodians was present it was decided to leave the material in situ.

\section{FUTURE PROSPECTS.}

Further archaeological work in the Aurukun Shire and other parts of Cape York should occur within the framework of a regional survey design, stratified according to geological/vegetation zones, and with due regard to existing knowledge of territorial systems. Once the determinants of site location and survival are understood, more specialized studies of chronology and settlement systems might proceed. In view of the marked linearity of environmental zones, the optimal sampling strategy would appear to be one based on random or systematic east-west transects. The logistics involved in such an operation in terrain as rough and inaccessible as Cape York would nevertheless be formidable. More intensive 
study of certain features in the archaeological landscape, such as the Love River and Ward River mounds is also desirable. The decision as to whether such a study should proceed rests with the custodians of the estates concerned and, in view of the fact that most of the mound sites are story places, this must necessarily involve a long process of consultation. The onus is on archaeologists to demonstrate the value of this kind of information as a local as well as a scientific resource.

While it cannot be claimed that the present residents of Aurukun still participate in a traditional lifestyle or subsistence system, many of their number are heavily involved in a traditional system of knowledge based on a relationship to country. This poses a challenge to archaeologists. Pleas for the integration of archaeological and ethnographic knowledge are less often heard today than was the case a decade ago. Certainly the indiscriminant application of ethnographic and ethnohistorical analogies is to be avoided. However the archaeological study of ancient settlement patterns can benefit greatly from information on contemporary territorial systems as well as specific ethnoarchaeological investigations of site formation processes. There are also sound practical reasons for integrating any future archaeological work with the community's own programs of site mapping and outstation development, in conjunction with ongoing research by social anthropologists.

\section{ACKNOWLEDGMENTS}

I am indebted to the custodians of the estates on which mapping work was carried out - - particularly Rex and Cecil Wolmbeng, Isobel Wolmby, George Sydney Yunkaporta and Charles and Alfred Taisman -- also to Dave Martin for advice and practical help. Thanks are also due to Alan and Raymond Wolmby, Bill Fuller and the Aurukun Shire Council for help with transportation and logistics. The Australian Institute of Aboriginal studies provided funds for the 1985-86 season. Karen GowlettHolmes of the South Australian Museum assisted with the identification of shell specimens. Dermot smyth was responsible for defining the vegetation zones. I am also grateful to my colleagues Peter sutton and Athol chase for help in reviewing the paper -- any remaining errors are my own.

\section{REFERENCES CITED}

Bailey, G. 1975. The Role of Shell Middens in Prehistoric Bconomies. Unpublished PhD thesis, University of Cambridge.

Bailey, G. 1977. Sheli mounds, shell middens and raised beaches in the Cape York Peninsula. Mankind 11:132-143.

Beaton, J.M. 1985. Evidence for a coastal occupation time-lag at Princess Charlotte Bay (North queensland) and implications for coastal colonization and population growth theories for Aboriginal Australia. Archaeology in Oceania 20 (1):1-20.

Bowdler, S. 1977. The coastal colonization of Australia. in J. Allen, J.Golson and R.Jones (eds), Sunda and Sahul, pp. 205-246. London: Academic Press. 
Campbel1, 1984. Extending the archaeological frontier: a review of work on the prehistory of North queensland. Queensland Archaeological Research 1:173-184.

Chappe11, J.M. 1982. Sea levels and sediments: some features of the context of coastal archaeological sites in the tropics. Archaeology in Oceania 17:69-78.

Chappel1, J.M. 1983. Evidence for smoothly falling sea level relative to North Queensland, Australia, during the past 6,000 yr. Nature 302:406-8.

Chappell, J.M.; Rhodes, E.G., Thom, B.G. and Wallensky, E. 1982. Hydroisostacy and the sea-level isobase at 5500 BP in North Queensland, Australia. Marine Geology 49:81-90.

Chase, A.K. 1980. Which Way Now? Tradition, Continuity and Change in a North Queensland Aboriginal Community. Unpublished PhD thesis, University of Queensland.

Chase, A.K. 1984. Belonging to country: territory, identity and environment in Cape York Peninsula, northern Australia. In L.R. Hiatt (ed), Aboriginal Landowners, pp. 104-128. University of Sydney.

Chase, A.K. and von sturmer, J.S. 1980. Anthropology and botany: turning over a new leaf. Pacific Linguistics 59:289-301.

Cribb, R.L. (1986) Sites, people and archaeological information traps: a further transgressive episode from Cape York. Archaeology in Oceania $21(3): 171-174$.

Cribb, R.I. in press. A graphics system for site based anthropological data. Australian Aboriginal studies.

Hynes, R. and Chase, A.K. 1982. Plants, sites and domiculture: Aboriginal influence on plant communities, Cape York Peninsula. Archaeology in Oceania $17: 138-50$.

Isobel, R.F., A.A. Webb and G.G. Murtha 1968 Atlas of Australian Soils: Bxplanatory Data for Sheet 7, North Queensland. C.S.I.R.O, Melbourne University Press.

Jones, R. 1969. Firestick farming. Australian Natural History 16 : 224-226.

MacPherson, P. 1884. The oven-mounds of the Aborigines in Victoria. Journal and Proceedings of the Royal society of New South wales 18: 49-59.

McConnel, U. 1957. Kyths of the Mungkan. Melbourne: Melbourne University press.

Pedley, L. 1971. Plant communities of Cape York Peninsula. Proceedings of the Royal society of queensland 82: $51-74$.

Meehan, B. 1982. Shell Bed to Shell Midden. Canberra: Australian Institute of Aboriginal studies. 
Peterson, N. 1973. Campsite location amongst Australian hunter gatherers: archaeological and ethnographic evidence for a key determinant. Archaeology and Physical Anthropology in Oceania 8: 173-93.

Rhodes, E.G. 1980. Modes of Holocene Coastal Progradation, Gulf of Carpentaria. Unpub. PhD Thesis, Australian National University.

Rigsby, B. and Sutton, P. (eds.) Papers in Australian Linguistics, No. 13. Pacific Linguistics, Series A, No.59

Rosenfeld, A., Horton, D.R. and Winter, J.W. 1981. Art and Archaeology in the Laura Area, North Australia. Terra Australis 6.

Roth, W.E. 1901. Food, its search, capture and preparation. North Queensland Ethnography Bulletin 3:7-31.

Smart, J. 1976. The nature and origin of beach ridges, western Cape York Peninsula, Queensland. BMR Journal of Australian Geology and Geophysics 1:211-215.

Smart, J. 1977. Late Pleistocene sea level changes, Gulf of Carpentaria. Geology 5:755-9.

Smyth, D. 1981. Aboriginal occupation in the vicinity of the Archer Bend National Park. Unpublished Report to the Australian Institute of Aboriginal Studies.

Sturmer, J.R. von 1978. The wik Region: Economy, Territoriality and Totemism in western Cape York. Unpublished PhD Thesis, University of Queensland.

Sutton, P. (ed.) 1976. Languages of Cape York. Australian Institute of Aboriginal Studies, Canberra.

Sutton, P. (ed.) 1978. Wik: Aboriginal Society, Territory and Language at Cape Keerweer, Cape York Peninsula, Australia. Unpublished PhD thesis, University of Queensland.

Sutton, P. and Rigsby, B. 1982. People with 'politicks': management of land and personnel on Australia's Cape York Peningula. In N.M. Williams and E.S. Hunn (eds) Resource Managers: North American and Australian Hunter Gatherers, Westview Press, Colorado.

Thom, B.G. 1964. Origin of sand beach ridges. Australian Journal of Science $26: 351-2$.

Thom, B.G. and Chappell, J.M. 1975. Holocene sea levels in Australia. Search $6: 90-93$.

Thomson, D. F. 1939. The seasonal factor in human culture. Proceedings of the Prehistoric Society 5: .209-221.

Thomson, D.F. 1972. Kinship and behaviour in North queensland: a Preliminary Account of Kinship and Social Organization on Cape York Peninsula. Canberra: Australian Institute of Aboriginal studies 51. 
Valentin, H. 1961. The central west coast of Cape York Peninsula. Australian Geographer 8: 65-72.

Williams, E. 1985. Estimation of prehistoric populations of archaeological sites in southwestern Victoria: some problems. Archaeology -in Oceania 20: 73-80.

Wilson, B.R. and Gillett, K. 1971. Australian Shells. Sydney: Read Publishers.

Wright, R.V.S. 1971. Prehistory in the Cape York Peninsula. In D.J.Mulvaney and J.Golson (eds), Aboriginal Man and Environment in Australia, pp. 133-140. Canberra: Australian National University Press. 